Natural Hazards and Earth System Sciences (2001) 1: 221-231

(C) European Geophysical Society 2001

\title{
Evaluation of tsunami risk in the Lesser Antilles
}

\author{
N. Zahibo ${ }^{1}$ and E. N. Pelinovsky ${ }^{2}$ \\ ${ }^{1}$ Université Antilles Guyane, UFR Sciences Exactes et Naturelles Département de Physique, Laboratoire de Physique \\ Atmosphérique et Tropicale 97159 Pointe-à-Pitre Cedex, Guadeloupe (F.W.I.) \\ ${ }^{2}$ Laboratory of Hydrophysics and Nonlinear Acoustics, Institute of Applied Physics, Russian Academy of Sciences, 46 \\ Uljanov Street, 603950 Nizhny Novgorod, Russia
}

Received: 27 July 2001 - Revised: 11 February 2002 - Accepted: 14 February 2002

\begin{abstract}
The main goal of this study is to give the preliminary estimates of the tsunami risks for the Lesser Antilles. We investigated the available data of the tsunamis in the French West Indies using the historical data and catalogue of the tsunamis in the Lesser Antilles. In total, twenty-four (24) tsunamis were recorded in this area for last 400 years; sixteen (16) events of the seismic origin, five (5) events of volcanic origin and three (3) events of unknown source. Most of the tsunamigenic earthquakes (13) occurred in the Caribbean, and three tsunamis were generated during far away earthquakes (near the coasts of Portugal and Costa Rica). The estimates of tsunami risk are based on a preliminary analysis of the seismicity of the Caribbean area and the historical data of tsunamis. In particular, we investigate the occurrence of historical extreme runup tsunami data on Guadeloupe, and these data are revised after a survey in Guadeloupe.
\end{abstract}

\section{Introduction}

The evaluation of the risk of tsunami on the scales of the Lesser Antilles is closely related to the evaluation of the seismic and volcanologic risk. The seismic risk is high in this region, mainly because it results there from an active geodynamic context, also expressed by volcanic activity along a contact zone materialized by the arc of the Lesser Antilles, and the tectonic deformations in the vicinity of this contact zone. The Lesser Antilles volcanic arc draws a curve of $850 \mathrm{~km}$ in length and a $450 \mathrm{~km}$ ray. It runs from the southern American continental margin to the Anegada passage which marks the current limit with the Greater Antilles (shelf of Puerto Rico and Virgin Islands). The arc results from subduction of the American plate under the Caribbean plate (Fig. 1).

These movements of plates control the tectonic, volcanic and seismic activity of the Lesser Antilles arc. Each plate is also the seat of a network of major faults. The north and the east of the Caribbean corresponds to an active margin, related

Correspondence to: N. Zahibo (narcisse.zahibo@univ-ag.fr) to the subduction of the American plate under the Caribbean plate at a rate of about $2 \mathrm{~cm} / \mathrm{year}$. The subduction angle is stronger in the center of the arc (Martinique, $60^{\circ}$ ) than in the north (Guadeloupe, $50^{\circ}$ ) and the south. This type of subduction is considered as an intermediate type between the two fundamental types (BRGM, 1990):

- The "Chili" type, characterized by a high speed of convergence, a mode of compression in the overlaping plate and a strong coupling between the two plates. The subduction earthquakes are very strong (magnitude higher than 8);

- The "Mariane" type, characterized by a low speed of convergence, a mode of distension in the overlaping plate and, on the contrary, "a decoupling" of the plates. The subduction earthquakes are, in general, weaker than in the previous case.

Taking into account both the important age (about 100 millions years) of the American oceanic crust in subduction under the Lesser Antilles arc and the weak rate of convergence between the plates, we can retain a probable value of about 7.5 for the maximum magnitude of subduction earthquakes in the Caribbean. The distribution of historical earthquakes throughout the arc confirms such a probability (Fig. 2). We can notice that the seismicity of the Lesser Antilles is located for the major part in the eastern sector of the arc. The America/Caribbean subduction zone and the tectonic zone (inside the American plate), with its mechanisms of normal and reverse faults, are the zones likely to store the most energy and are thus, the potential sources of tsunami. Tectonic tsunamis are expected to be more important regionally than volcanic and landslide tsunamis.

Some theories (BRGM, 1990) estimate that the overlap of plates is strongly coupled and that the slip is partially and temporarily blocked on broad portions of the arc. This seems to explain the seismic "gap" east of Guadeloupe, identified by Dorel (1981) which is likely to be filled in the immediate 


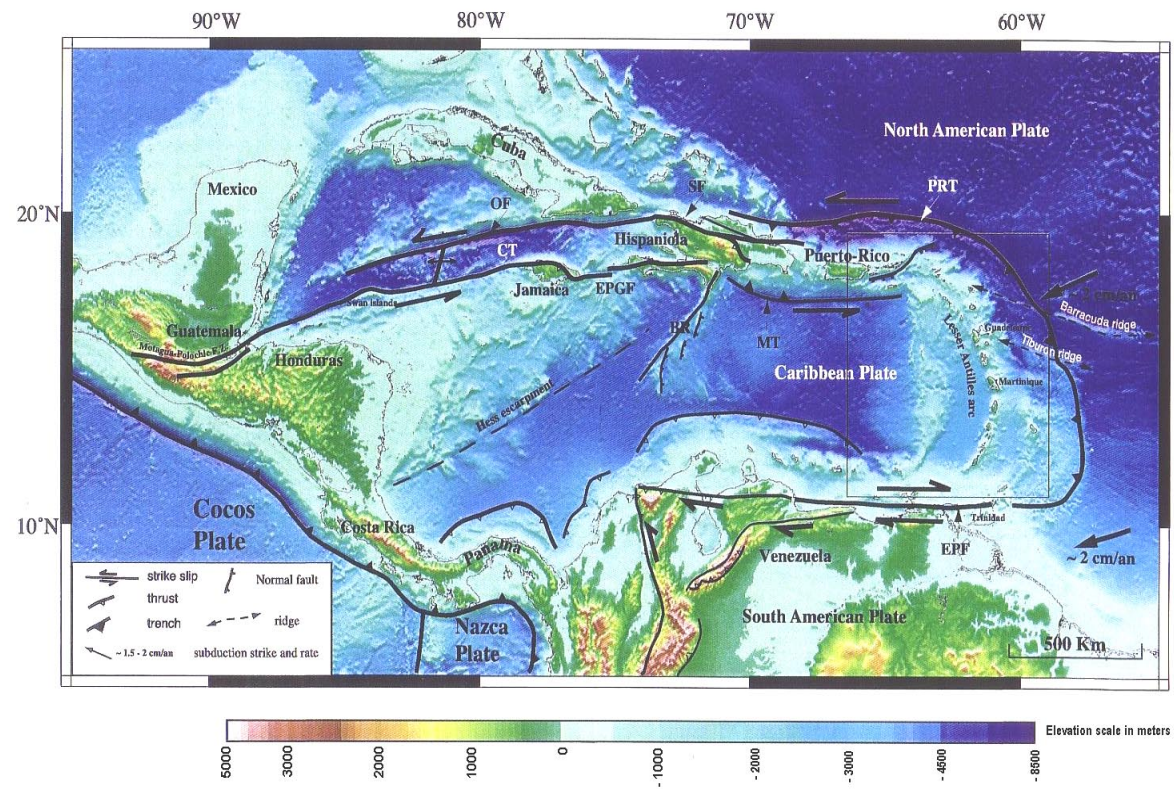

CT: Cayman Trough, OF: Orient Fault zone, SF: Septentrional Fault, EPGF: Eqilliro-Plantain Garden Fault zone; BR: Beta Ridge; MT: Muertos Trough; PRT: Puerto Rico Trench; EPF: EI Pilar Fault zone
Fig. 1. Geodynamic context, Bathymetry from Smith and Sandwell (1997). future by a very strong subduction earthquake, a probable source of tsunami.

Tsunamis in the Caribbean region are not very rare events. The first version of the Caribbean regional tsunami catalogue prepared by Lander and Whiteside (1997) covers the period from 1530 to 1991 and contains 56 events. For the last 100 years, the catalogue lists 20 tsunamis, about one every 5 years. There is a high probability of a tsunami occurring in the Caribbean comparable with other areas and this risk should be specially investigated. James Lander and Karin O'Loughlin are preparing the extended version of tsunami catalogue to be published soon in the special issue of the international journal "Natural Hazards". Weissert (1990) has calculated the tsunami travel time charts for the Caribbean Sea. The travel time for a complete crossing of the Caribbean is estimated at $3.2 \mathrm{~h}$ laterally and $1.5 \mathrm{~h}$ meridionally. These charts can be used for developing the regional tsunami warning system. Tsunamis of volcanic origin in the Caribbean were also studied, for instance, the numerical simulation shows that the potential debris avalanche in the Soufriere volcano (Montserrat, Lesser Antilles) can induce the tsunami waves of $1-2 \mathrm{~m}$ at distances of $10 \mathrm{~km}$ from the generated area (Heinrich et al., 1998).

The goal of this paper is to study the tsunami hazard in the Lesser Antilles, the group of islands from Anguilla in the north, to Trinidad and Tobago in the south. The location of the Lesser Antilles Islands is shown in Fig. 3. Data of historical tsunamis in this area are discussed in Sect. 2. They are analyzed in Sect. 3. The rough estimations of the tsunami risk for some islands of the Lesser Antilles (Antigua, Barbados) are presented. Results of a field trip in Guadeloupe (France), where the extreme high tsunami wave heights $(18 \mathrm{~m})$ were recorded during two tsunamis, are discussed in Sect. 4. These historical data are revised.

\section{Historical tsunami data}

Recently, the tsunami catalogue for the whole Caribbean Sea was prepared (Lander and Whiteside, 1997). Also, data from the NOAA/NESDIS National Geophysical Data Center is used. Not all sources and original descriptions are available now; this leads to the preliminary character of results. Nevertheless, some rough conclusions can be done for an estimation of tsunami risk for the Lesser Antilles. According to the available data, 24 tsunami events in the Lesser Antilles can be selected for the whole historical period. The earthquakes produced most of the events (16). Sometimes the origin of tsunami is not quite clear, because heavy weather conditions were at the time of the shocks. Four tsunamis are from volcanic eruption origin. The source of three tsunamis is unknown.

\subsection{Tsunami of the seismic origin (16 events)}

First of all, the two teletsunamis, which crossed the Atlantic, should be mentioned.

1 November 1755 . The significant tsunami (with maximal height of $7 \mathrm{~m}$ ) was induced by the famous Lisbon earthquake. The tsunami waves crossed the Atlantic Ocean for 7-8 h and manifested on many islands of the Lesser Antilles. Table 1 contains the observed runup heights in the Lesser Antilles taken from NOAA/NESDIS web site $^{1}$. Lander and Whiteside (1997) give wave heights $1.5-1.8 \mathrm{~m}$ for Barbados (not 0.8-1.5 $\mathrm{m}$ as in Table 1) and add, "the water was

\footnotetext{
${ }^{1}$ Coordinates of some locations are corrected
} 


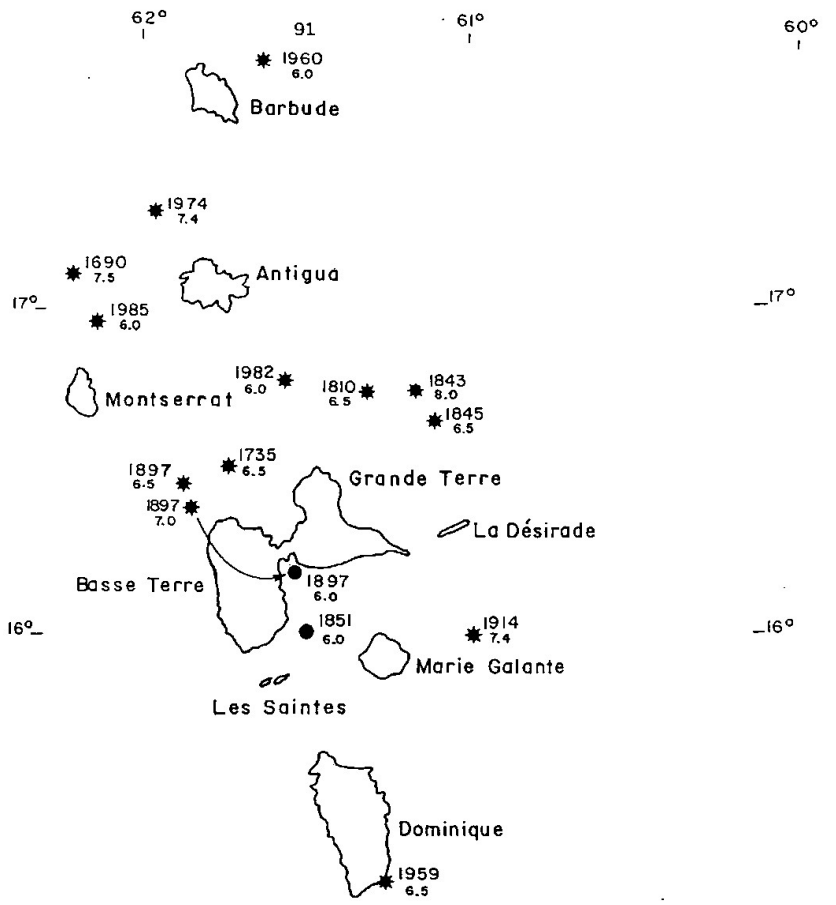

Epicenter and magnitude according to Feuillard (1985)

- Revised epicentre according to BRGM (1990)

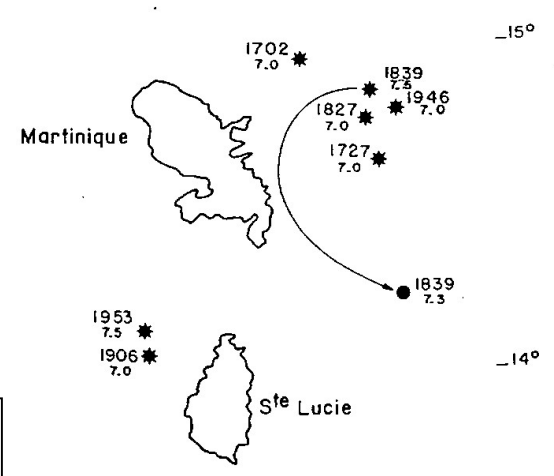

Some far major earthquakes weakly felt in Guadeloupe are not represented

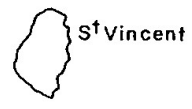

Fig. 2. Historic seismicity: localisation of the area of the most probable epicenters of the strongest historical earthquakes felt in Guadeloupe.

Table 1. Runup heights of the 1755 teletsunami in Lesser Antilles

\begin{tabular}{llclcl}
\hline Country & Location & Lat. N & Long. W & Run-up (m) & Remarks \\
\hline Barbados & Barbados & 13.08 & 57.62 & 1.5 & Period of 5 min. \\
Barbados & Carlisle Bay & 13.08 & 57.62 & 0.8 & \\
France & Martinique & 14.67 & 61.00 & & $\begin{array}{l}\text { Sea withdrew for 1.6 km and then } \\
\text { flowed into upper floors of houses. }\end{array}$ \\
Dominica & & & & & \\
Dominica & Dominica & 15.42 & 61.33 & 3.6 & \\
Antigua and Barbuda & Portsmouth & 15.58 & 61.47 & 3.7 & \\
Netherlands & Antigua & 17.05 & 61.80 & 3.7 & \\
France & Saba & 17.63 & 63.23 & 7.0 & Sloop anchored in 4.6 m water was \\
& St. Martin & 18.07 & 63.07 & 4.5 & \\
\hline
\end{tabular}




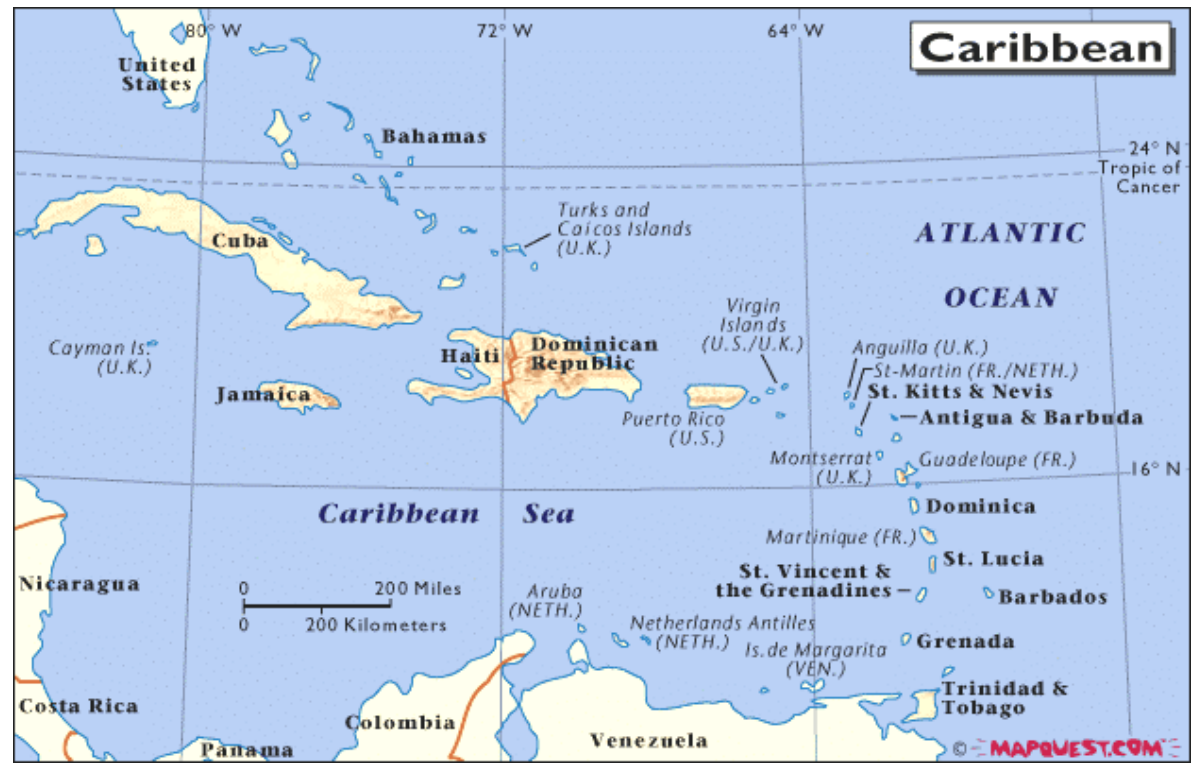

Fig. 3. The chart of the Caribbean Sea.

Table 2. Runup heights of the 1751 tsunami in Lesser Antilles

\begin{tabular}{|c|c|c|c|c|}
\hline Location & Lat. N & Long. W & $\begin{array}{l}\text { Run-up } \\
\text { (m) }\end{array}$ & Remarks \\
\hline Barbados & 13.17 & 59.53 & 3.6 & $\begin{array}{l}\text { Portion of } \\
\text { coast fell } \\
\text { into the sea }\end{array}$ \\
\hline Martinique & 14.67 & 61.00 & 1.8 & \\
\hline Antigua & $12.00 ?$ & $62.00 ?$ & 4.5 & \\
\hline St. Martin & 18.07 & 63.07 & 7.0 & \\
\hline
\end{tabular}

black as ink" relating this to a possible local landslide. They also pointed out that "the lowlands on most of the other French Islands were inundated". An agitation of the sea at Antigua is also reported by Affleck (1809).

31 March 1761. The second teletsunami was generated again by an earthquake close to Lisbon in 1761, and it "caused an extraordinary flux and reflux of the sea at Barbados" (Lander and Whiteside, 1997). Wave height is $1.2 \mathrm{~m}$ according to NOAA/NESDIS data.

The other 14 events have been induced by the earthquakes that occurred in the Caribbean Sea or with unknown locations (some of them probably had atmospheric origin). Below are the descriptions of these events.

20 November 1751 . Tsunami wave heights induced by the earthquake (its parameters are unknown) are given in Table 2 taken from NOAA/NESDID web site (coordinates of Antigua are corrected).

19 March 1802. Coordinates of the earthquake epicenter: $17.2^{\circ} \mathrm{N}$ $62.4^{\circ} \mathrm{W}$. It was accompanied by great agitation of the sea at Antigua and St. Kitts (St. Christopher) Islands (NOAA/NESDIS data).

30 November 1823. At 14:45 LT, a strong earthquake (epicenter coordinates: $14.4^{\circ} \mathrm{N} 61.1^{\circ} \mathrm{W}$; NOAA/NESDIS data) was followed by a tidal wave at 15:10 LT, which caused some damage in Saint Pierre Harbour, Martinique (Lander and Whiteside, 1997).

9-13 September 1824. Earthquakes were felt at Basse Terre (Guadeloupe) on 9 and 13 September. There was a remarkable rise and fall of the tide at Plymouth (Montserrat). There had been a terrible storm and heavy rain on 7-9 September (Lander and Whiteside, 1997).

30 November 1824,. Severe shocks at Saint Pierre Harbor (Martinique) were reported. A very high tide threw many ships upon the strand. Heavy rain followed lasting 10 days (Lander and Whiteside, 1997).

3 December 1831. An earthquake occurred. The sea was in a state of violent agitation on Trinidad, Antigua and St. Kitts (St. Christopher) Islands. Note the large distance between reporting areas. An earthquake was also reported at Grenada, St. Vincent (Lander and Whiteside, 1997).

7 May 1842. A strong earthquake (magnitude $>8.0$; epicenter coordinates: $18.5^{\circ} \mathrm{N} 72.5^{\circ} \mathrm{W}$ ) at $17: 30 \mathrm{LT}$ produced the tsunami waves (Lander and Whiteside, 1997). Their heights are summarized in Table 3 (NOAA/NESDIS data). Coordinates of Gouyave and Grenada in Table 3 are corrected. Lander and Whiteside (1997) give $8.3 \mathrm{~m}$ for Deshaies and $1.8 \mathrm{~m}$ for Sainte-Rose.

8 February 1843. A strong earthquake (magnitude, 8.3; coordinates, $16.5^{\circ} \mathrm{N} 62.2^{\circ} \mathrm{W}$; depth $<50 \mathrm{~km}$; NOAA/NESDIS data) was felt at Guadeloupe, St. Lucia, St. Kilts, Montserrat, Martinique, and other islands. The sea rose $1.2 \mathrm{~m}$ at Antigua but sank again immediately (Lander and Whiteside, 1997). The motion of the sea on the coast at Pointe-à-Pitre (Guadeloupe) was, in fact, rather weak. Water barely invaded the quays of the city on some steps, which were, however, relatively low about its level. It had been similar in Basse-Terre and Isles de Saintes (Guadeloupe), in Dominica, etc. (Sainte-Claire Deville, 1867).

18 November 1867. An earthquake (magnitude, 7.5, depth $<50 \mathrm{~km}$, epicenter coordinates: $18.5^{\circ} \mathrm{N} 65.5^{\circ} \mathrm{W}$ ) occurred in the 
Table 3. Runup heights of the 1842 tsunami in Lesser Antilles

\begin{tabular}{lcccl}
\hline Location & Lat. N & Long. W & Run-up (m) & Remarks \\
\hline Gouyave, Grenada & & & & All floatable objects carried away \\
Bass-Terre, Guadeloupe & 16.00 & -61.73 & 0.9 & \\
Deshaies, Guadeloupe & 16.30 & -61.58 & 18.3 & 20 m wave carried off floatable objects \\
Sainte-Rose, Guadeloupe & 16.33 & -61.70 & 18.3 & 20 m wave carried off floatable objects \\
St. John's, Antigua & 17.13 & -61.85 & 3.1 & \\
\hline
\end{tabular}

Table 4. Runup heights of the 1867 tsunami in Lesser Antilles

\begin{tabular}{lcccl}
\hline Location & Lat. N & Long. W & Run-up (m) & Remarks \\
\hline St. George's, Grenada & 12.05 & -61.75 & 1.5 & \\
Gouyave, Grenada & 12.15 & -61.73 & 3.0 & \\
$\begin{array}{l}\text { Basse Terre, Guadeloupe } \\
\text { Deshaies, Guadeloupe }\end{array}$ & 16.00 & -61.71 & 1.0 & Sea retreated far from coast \\
Sainte-Rose, Guadeloupe & 16.30 & -61.78 & 18.3 & $\begin{array}{l}\text { Houses destroyed, sea receded } \\
100 \mathrm{~m} \text { and returned as a 18.3 m wave }\end{array}$ \\
St. John's, Antigua & 17.16 & -61.70 & 10.0 & $\begin{array}{l}\text { Sea withdrew 100 m and } \\
\text { damaged houses, upon a return 10 m wave }\end{array}$ \\
\hline
\end{tabular}

Virgin Islands. It induced tsunami waves; their heights are given in Table 4 (NOAA/NESDIS data). At St. Barthelemy and St. Martin, there was some damage; at St. Vincent and Martinique, there was unusually high water; at Pointe-à-Pitre and Isles des Saintes (Guadeloupe), there was a slight swell.

11 March 1874. A submarine shock to the southeast of St. Thomas (Virgin Islands) shook the island and ships in the harbor. At Dominica, the steamer Corsica reported at 05:00 LT a series of heavy rollers in the harbor during half an hour, rendering communication with the shore impossible. They did not feel the earthquake (Lander and Whiteside, 1997).

25 December 1969. Earthquake had parameters: magnitude, 7.0; depth $15 \mathrm{~km}$; epicenter coordinate, $15.8^{\circ} \mathrm{N} 59.7^{\circ} \mathrm{W}$. Tsunami with the height of $0.1 \mathrm{~m}$ was recorded in Barbados, Dominica and Antigua (NOAA/NESDIS data). Lander and Whiteside (1997) give the maximum amplitude $46 \mathrm{~cm}$ at Barbados.

16 March 1985. A moderate earthquake caused damage at Montserrat. It was felt at Antigua and St. Kitts. A several cm tsunami were recorded at Basse Terre, Guadeloupe (Lander and Whiteside, 1997). NOAA/NESDIS gives for earthquake: $M_{w}=6.4$; depth $14 \mathrm{~km}$; epicenter coordinates, $17.0^{\circ} \mathrm{N} 62.5^{\circ} \mathrm{W}$. We can observe that this moderate earthquake generated tsunami due to the its low depth.

22 April 1991. A major earthquake of magnitude 7.4 struck the region surrounding the eastern border of Costa Rica and Panama ${ }^{2}$. The epicenter $\left(9.6^{\circ} \mathrm{N} 83.4^{\circ} \mathrm{W}\right)$ was at a depth of about $17 \mathrm{~km}$. The reviewer indicates that there are some stories of a tsunami observed in a bay of the Martinique.

9 July 1997. Earthquake had parameters: $M_{w}=6.9$; depth $15 \mathrm{~km}$; epicenter coordinates, $10.6^{\circ} \mathrm{N} 63.5^{\circ} \mathrm{W}$. There is information of a

\footnotetext{
${ }^{2}$ data from www.eqe.com/publications/costaric/costaric.htm
}

tsunami at Tobago (NOAA/NESDIS data). The very low depth of this moderate earthquake is probably responsible for the generation of the tsunami.

\subsection{Tsunamis of volcanic origin (5 events)}

Data of tsunamis of volcanic eruption are more rare (NOAA/NESDIS data).

17 February 1842. Probably, the volcanic eruption produced minor a tsunami at Antigua.

5 May 1902. In 1902, the volcanic eruption of the Montagne Pelée in Martinique occurred from 2 May to 8 May. On 5 May 1902, a 35-m-lahar from Montagne Pelée swept down Rivière Blanche, north of the nearby town of St. Pierre. When it reached the sea, it generated a 4-5 $\mathrm{m}$ high tsunami that only affected the lower part of the town, killing one hundred people (Bryant, 2001).

7 May 1902. The 7 May 1902 eruption produced a pyroclastic flow that swept into the harbour of St. Pierre and generated a tsunami that traveled as far as Fort de France, $19 \mathrm{~km}$ away (Bryant, 2001).

3 March 1911. The extraordinary waves noticed on the coast of Trinidad and Tobago were following an explosion of mud-volcano island. No quantitative information about the tsunami characteristics is available.

26 December 1997. A tsunami was observed in the southern part of Montserat, generated by a pyroclastic flow (Cader et al., 1998). It is necessary to mention that the numerical simulation by Heinrich et al. $(1998,1999 a, b)$ shows the potential danger of the tsunami appearance at the possible eruption of the Soufriere volcano (Montserrat). Table 8 summarizes the locations due to these volcanic eruptions. 
Table 5. Tsunami heights at Antigua

\begin{tabular}{lllllll}
\hline Year & 1751 & 1755 & 1842 & 1843 & 1867 & 1969 \\
\hline Runup (m) & 4.5 & 3.7 & 3.1 & 1.2 & 3 & 0.1 \\
\hline
\end{tabular}

Table 6. Tsunami heights at Barbados

\begin{tabular}{lllll}
\hline Year & 1751 & 1755 & 1761 & 1969 \\
\hline Runup $(\mathrm{m})$ & 3.6 & 1.5 & 1.2 & 0.46 \\
\hline
\end{tabular}

\subsection{Tsunamis of unknown origin (3 events)}

24 April 1767. The sea was much agitated and had ebbed and flowed in an unusual way at Barbados and Martinique (Lander and Whiteside, 1997).

26 July 1837. Large waves were reported at Martinique (NOAA/NESDIS data).

2 August 1837. Several shocks accompanied by a large wave occurring during a hurricane at Martinique. The source of wave is uncertain (Lander and Whitesite, 1997).

\section{Preliminary analysis of historical tsunamis}

The quantitative information of the parameters of the tsunamis given above is not quite good enough for statistical analysis. But we should mention that the total number (21) of tsunami events for the period 1530-2000 is high, and the return period for the Lesser Antilles, as a whole, can be estimated in 24 years. This value of the return period is characterized for other regions of the Atlantic, for instance, for the Mediterranean (Soloviev et al., 2000; Pelinovsky et al., 2002). So, the risk of tsunamis for the Lesser Antilles seems to be real.

For estimation of the tsunami risk for each island of the Lesser Antilles, the historical data should be collected for each location. In fact, only a few data are available for some locations in the Lesser Antilles, as a rule, one to three values. The maximal number of runup heights is known for the Antigua Island, summarized in Table 5. Considering the total period of observation as above over 470 years, the cumulative frequency of tsunami appearance can be calculated (Fig. 4). Roughly speaking, the return period of the tsunami wave with runup exceeding $2-3 \mathrm{~m}$ can be estimated in 100 years. For Barbados, tsunamis runup are known for the four events only (Table 6). The calculated cumulative frequency for tsunamis in Barbados is presented in Fig. 4 as well. The curves for Antigua and Barbados located in different parts of the Lesser Antilles, are relatively close to each other; this demonstrates the same character of tsunami manifestations on both islands. The regression line: cumulative frequency

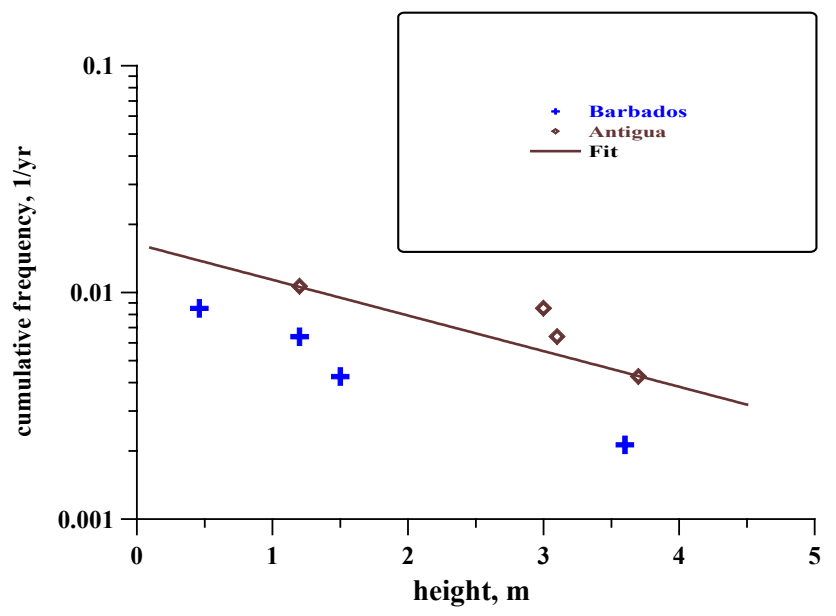

Fig. 4. Occurrence of tsunamis in Barbados and Antigua Islands.

$(1 / h)$ - wave height $(m)$, based on data for Antigua is

1n $f=0,36 H-4.11$

and is also presented in Fig. 4 by the solid line. This regression can be used for the rough estimation of the tsunami appearance at the Lesser Antilles. In particular, its value for weak amplitudes, $f=0.0151 /$ year, characterizes the frequency of occurrence of tsunamis in the region. Due to the common origin of tsunami by the underwater earthquakes in the Caribbean, this value should be the same (or slowly varied) for each island. The characteristic slope of this curve, of course, depends on the bathymetry of each island and should vary more significantly from one island to another. It cannot be found from given historical data, and this numerical simulation of the tsunami propagation may be effective in generating missing data for each island. Such an approach to create the synthetic tsunami catalogue for other regions is discussed, for instance, by Curtis and Pelinovsky (1999) and Choi et al. (2001). It will be developed for the tsunamis in the Lesser Antilles.

For the successful numerical simulation of the tsunami propagation, the parameters of tsunamigeneric earthquakes should be analyzed. Table 7 summarizes quantitative information of 13 tsunamigeneric earthquakes that occurred in the Caribbean Sea with known or unknown coordinates ${ }^{3}$. The epicenters are known for 8 events (they are presented in Fig. 5); the earthquake magnitude is given for 6 events, and only 5 events with "good" seismic data are provided by the observed tsunami wave heights.

First of all, we may mention that 5 tsunamigeneric earthquakes (from 8 documented events) occurred in the Lesser Antilles directly. Two strong tsunamis were initiated by the earthquakes at the Greater Antilles (Haiti, 1842, and Virgin Islands, 1867). The earthquake in South America induced

\footnotetext{
${ }^{3}$ Figure 2 shows additionally the 6 closest earthquakes with magnitudes higher than 7 which can potentially generate tsunami, but no data for these events is available.
} 
Table 7. Parameters of tsunamigenic earthquakes for the Lesser Antilles

\begin{tabular}{|c|c|c|c|c|c|c|}
\hline Date & Lat. $\mathrm{N}$ & Long. W & Magnitude $M_{w}$ & Depth, km & Area location of effects (Lander 1997) & $\begin{array}{l}\text { Runup } \\
\text { (m) }\end{array}$ \\
\hline 20 November 1751 & & & & & St. Martin, Antigua, Martinique, Barbados & 7 \\
\hline 19 March 1802 & 17.2 & 62.4 & & & Antigua, St. Kitts & \\
\hline 30 November 1823 & 14.4 & 61.1 & & & Martinique & \\
\hline 13 September 1824 & & & & & Montserrat & \\
\hline 30 November 1824 & & & & & Martinique & \\
\hline 3 December 1831 & & & & & Trinidad, Antigua, St. Kitts & \\
\hline 7 May 1842 & 18.5 & 72.5 & $>8.0$ & $<50 \mathrm{~km}$ & Guadeloupe, Grenada, Antigua & 18.3 \\
\hline 8 February 1843 & 16.5 & 62.2 & $>8.0$ & $<50 \mathrm{~km}$ & Antigua & 1.2 \\
\hline 18 November 1867 & 18.5 & 65.0 & 7.5 & $<50 \mathrm{~km}$ & $\begin{array}{l}\text { St. Martin, St. Barthelemy, Antigua, } \\
\text { Guadeloupe, Martinique, St. Vincent, Grenada }\end{array}$ & 18.3 \\
\hline 11 March 1874 & & & & & Dominica & \\
\hline 25 December 1969 & 15.8 & 59.7 & 7.0 & 15 & Barbados, Antigua, Dominica & 0.46 \\
\hline 16 March 1985 & 17.0 & 62.5 & 6.4 & 14 & Guadeloupe & 0.1 \\
\hline 9 July 1997 & 10.6 & 63.5 & 6.9 & 15 & Tobago & \\
\hline
\end{tabular}

Table 8. Location of landslide or pyroclastic flows due to volcanic eruptions

\begin{tabular}{llll}
\hline Date & Island & Lat. N & Long. W \\
\hline 17 February 1842 & Antigua & 16.5 & 62.2 \\
5 May 1902 & Martinique & 14.4 & 61.0 \\
7 May 1902 & Martinique & 14.4 & 61.0 \\
3 March 1911 & Trinidad and Tobago & 9.5 & 61.00 \\
26 December 1997 & Montserrat & 17 & 62 \\
\hline
\end{tabular}

Table 9. Focal depth of earthquakes in the Lesser Antilles with magnitude larger than 7

\begin{tabular}{|c|c|c|}
\hline Earthquakes & Magnitude $M_{w}$ & Depth \\
\hline 1690 & 7.5 & $<50 \mathrm{~km}$ \\
\hline 1839 & 7.3 & $>50 \mathrm{~km}$ \\
\hline 1843 & 8.0 & $30 \mathrm{~km}$ \\
\hline 3 October 1914 & 7.4 & $100 \mathrm{~km}$ \\
\hline 1953 & 7.5 & $>50 \mathrm{~km}$ \\
\hline 8 October 1974 & 7.4 & $40 \mathrm{~km}$ \\
\hline
\end{tabular}

a weak tsunami at Tobago. We should also add two teletsunamis that arrived from Portugal. So, the tsunamis at the Lesser Antilles can be related with both the closest and the far away earthquakes.

The earthquakes with magnitudes 6.3-7.0 generated weak tsunamis (maximum recorded height is $46 \mathrm{~cm})^{4}$. Significant tsunamis were initiated by the strong earthquakes with a magnitude more than 7.5. This is typical for the Pacific

\footnotetext{
${ }^{4}$ The physical mechanism of tsunami generation by weak earthquakes is not quite clear. Probably, they initiated submarine landslides and this should be a subject of special investigation.
}

Ocean as well and characterizes the general properties of the mechanism of the tsunami generation. Table 9 summarizes the focal depth of 6 earthquakes with magnitude larger than 7, very close to the Lesser Antilles arc (BRGM, 1990). The earthquakes of 1839, 1914 and 1953 had a depth larger than $50 \mathrm{~km}$. It is not quite clear why the strongest yet shallow earthquake in 1843 (magnitude $>8.0$; depth $<50 \mathrm{~km}$ ) occurred in the triangle of Guadeloupe, Montserrat and Antigua, induced relatively weak tsunamis which were reported at Guadeloupe, Dominica and Antigua (in last location, the wave height was $1.2 \mathrm{~m}$ ); the original observation data of the 1843 tsunami should be checked. There are no available tsunami data about the shallow earthquakes of 1690 and 1974 that occurred near Antigua.

For numerical simulation, the 1867 event is of great interest, because it was felt on most islands of the Lesser Antilles, as well on the Greater Antilles (in particular, maximum height at the Virgin Islands, near the epicenter, was reported as $9 \mathrm{~m}$ in Frederiksted Harbour, St. Croix Island); this is well documented (Reid and Taber, 1920; Murty, 1977). Below is the description of this event for Lesser Antilles taken from the paper by Reid and Taber (1920) written 50 years later after tsunami:

"Still farther east some damage was done in the islands of Saba, St. Martin, and St. Bartholomew; a high wave is said to have invaded Saba Island; and the sea rose pretty high at St. Christopher. In Antigua the shock was called "severe", which must be an exaggeration, probably due to the alarm caused by the sea, which was reported to have risen eight or ten feet in the harbor of St. John, on the west coast of the Island. The shock was weakly felt in Guadeloupe and Marie Galante, and apparently not at all in Martinique. There is no report from Dominica, but it is possible that the shock was barely sensible there. At Basse-Terre, Guadeloupe, "towards three o'clock", the sea suddenly retired a long distance and then "after a certain interval", advanced; this phenomenon 


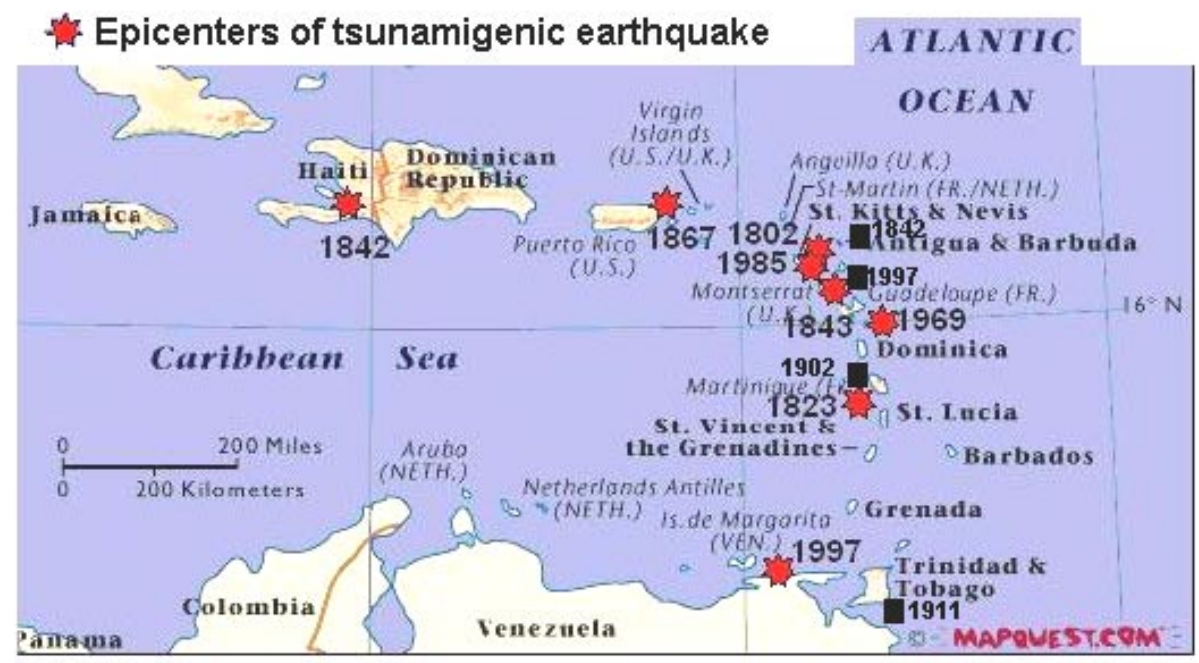

- Tsunamigenic landslide or pyroclastic flows
Fig. 5. The chart of the Caribbean Sea with epicenters of tsunamigenic earthquakes and location of tsunamigenic landslide in the Lesser Antilles. was repeated once, and then all was quiet. The total range in the height of the sea from its lowest to its highest level was about two meters. From Deshayes and Sainte-Rose, in the northwest part of the island, comes a more sensational report; the sea is said to have withdrawn and to have returned in a wave "at least 60 feet high", which broke over the shore and carried off all floatable objects. Three of these great waves are described. The account is undoubtedly much exaggerated. In both the accounts from Guadeloupe the waves are said to have arrived at about three o'clock, and immediately after the light shocks. There was an error either in the report or in the clocks of the island; probably in both; for the shock must have been felt at about three o'clock local time, and the waves must have arrived about one hour later. Point-à-Pitre, on the southern side of the island, seems to have felt the shock, but it is so protected, at the head of the Petit-Cul-de-Sac, that the waves were barely, if at all, noticeable there. The waves were also noted at Martinique, but we have no description of them. At St. Vincent "the water was observed to be unusually high; but nothing occurred to attract attention", though at Becquia Island, ten or fifteen miles farther south, there were three great slow waves, the water rising about six feet above its usual level; the whole event lasted about forty minutes, and the water was not in the least agitated. The next island from which we have a report is Grenada; at St. George, about 17:20 LT, the sea suddenly sank four or five feet, leaving the reef, in front of the lagoon, bare; it then rose as much. This was repeated six times and then all was quiet. At Gouyave, nearby, the sea began to ebb and flow about 17:00 LT with a range of about twenty feet, doing some damage to the town. Twenty feet seems to be an exaggeration; the time of the waves seems also inaccurate; they would have arrived there at about 16:30 LT. The shock was not felt at Grenada; the slight shocks felt in that island at 21:00 LT, 18 November and 01:00 LT on the 19 November were probably connected with the strong shock on the South
American coast on 19 November."

The surprising information of $18.3 \mathrm{~m}$ at Guadeloupe during the 1867 event, and also during the 1842 event, should be specially inspected, taking into account the contradiction between data in various sources.

\section{Have extreme wave heights occurred in Guadeloupe?}

Analysis of tsunami wave heights for whole historical period at the Lesser Antilles shows that the extreme wave heights of the same value in $18.3 \mathrm{~m}$ (or 60 feet) were recorded in Guadeloupe only during the tsunamis of 1842 and 1867 . They were recorded in the northwestern part of the island, at Deshaies and Sainte-Rose (Fig. 6). Reid and Taber (1920) mentioned that this is an overestimation for the 1867 event. At first, let us systematize the descriptions of tsunamis in these locations.

7 May 1842. A strong earthquake (magnitude $>8.0$ ) occurred at Haiti. There was extensive destruction caused by the earthquake and tsunami; at Port-de-Paix the sea receded $60 \mathrm{~m}$ and the returning wave covered the city with $5 \mathrm{~m}$ of water. About 200-300 of the city's 3000 inhabitants were killed by the earthquake and tsunami (NOAA/NESDIS data and Lander and Whiteside, 1997).

The description of the tsunami in both locations in Guadeloupe, at Deshaies and Sainte-Rose, is the same: a wave carried away all floatable objects. There is no information of damage in villages. According to the NOAA/NESDIS data, the wave runup height was $18.3 \mathrm{~m}$ in both locations. According to Lander and Whiteside (1997), the wave runup height was $8.3 \mathrm{~m}$ at Deshaies and $1.8 \mathrm{~m}$ at Sainte-Rose.

18 November 1867 . This earthquake had the lesser magnitude (7.5), but it was closer to Guadeloupe; its epicenter was at the Virgin Islands.

According to NOAA/NESDIS data, the tsunami wave runup height at Deshaies was $18.3 \mathrm{~m}$. Houses were destroyed; the 


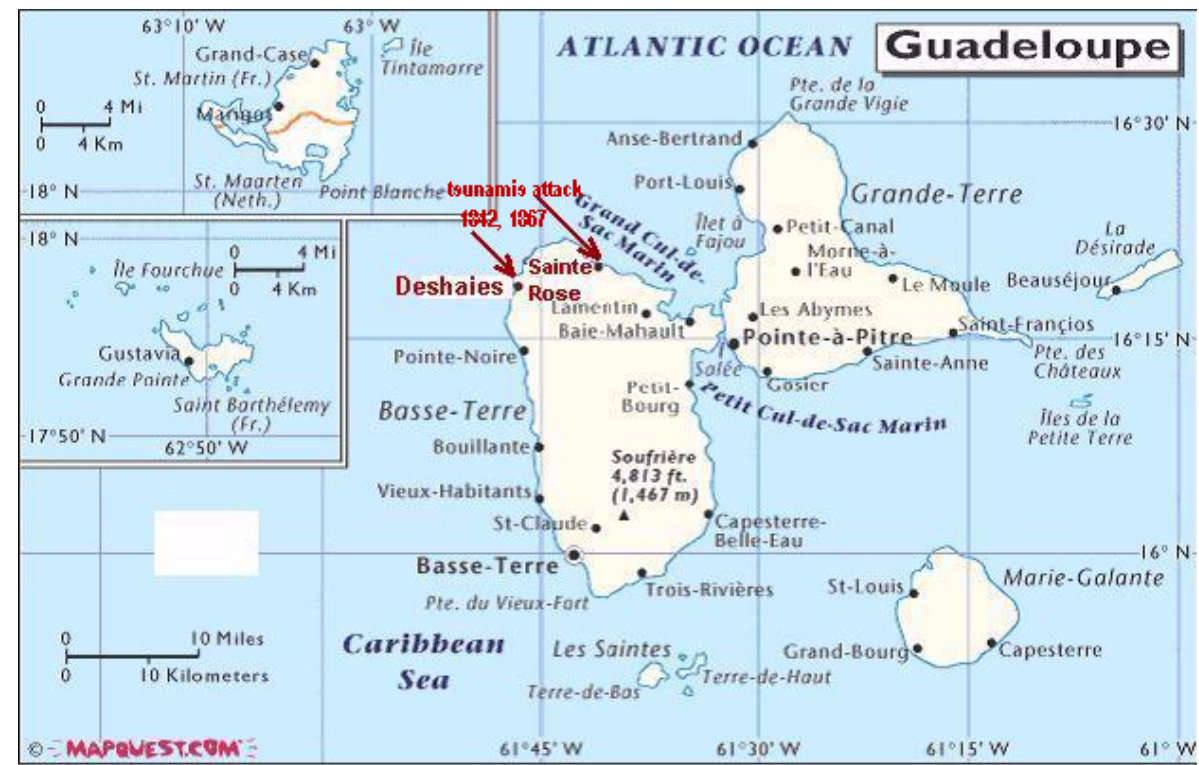

Fig. 6. Map of Guadeloupe. sea receded $100 \mathrm{~m}$, and returned as a $18.3 \mathrm{~m}$ wave. At SainteRose, the wave runup height was $10 \mathrm{~m}$. The sea withdrew $100 \mathrm{~m}$ and damaged houses upon return as a $10 \mathrm{~m}$ wave.

According to Lander and Whiteside (1997), at Deshaies, houses in the village were destroyed. At Sainte-Rose, there was a $10 \mathrm{~m}$ wave. The sea withdrew $100 \mathrm{~m}$ and flooded and damaged houses on return.

According to Reid and Taber (1920), from Deshaies and Sainte-Rose, comes a more sensational report; the sea is said to have withdrawn and to have returned in a wave "at least 60 feet high", which broke over the shore and carried off all floatable objects. Three of these great waves are described. According to Murty (1977), at Deshaies and Sainte-Rose, the tsunami runup was said to have exceeded $18.3 \mathrm{~m}$.

The papers cited above give the same description of phenomenon for both locations: the first wave has the negative polarity and the sea withdrew $100 \mathrm{~m}$. The second wave was positive and it climbed on the beach (probably, as the broken wave; see Reid and Taber, 1920), destroying houses. The difference is in the height of the crest: $18.3 \mathrm{~m}$ in both locations; or $18.3 \mathrm{~m}$ at Deshaies and $10 \mathrm{~m}$ at Sainte-Rose. Also, Reid and Taber (1920) informed us that this large wave carried off all floatable objects, and in total, three large waves were observed. Reid and Taber (1920) cited an original letter from Sainte-Claire Deville (1867). We found this letter; it gives the following description of tsunami (translating from French). At Deshaies, one writes: Great disaster! The sea devastated and thrusted almost all the houses of the village. It is no longer possible to have bread. The inhabitants took refuge in the church.

An inhabitant of Sainte-Rose wrote: "Today, around 15:00 LT, the sea suddenly receded on more than one hundred meters of the littoral; this withdrawal was preceded by light oscillations from an earthquake, of which the duration can be estimated at five or six seconds. Then suddenly, a first blade, at least 60 feet high, rising about 3 miles to the north in the open sea has rolled violently towards the ground, immersing all the littoral and flooding the houses. A second and third of these enormous blades, rolling from north to south, followed, with short intervals, reversing all in their passage."

Also, this letter informs us of tsunami waves in other locations of Guadeloupe. At Basse-Terre, around 15:00 LT, the sea suddenly receded from the land on a long distance. After a certain time, it returned to its level. The population was very frightened but there was no damage. In the harbor of Pointe-à-Pitre, the variation of the sea level and coast were less. So, the original letter informs us of a large wave (60 feet) in the open sea at a distance of 3 miles from SainteRose, and the accuracy of such an estimation should be very low. Also, there is no information about wave height at Deshaies.

For an investigation of the possibility of these descriptions, the inspection trip to Deshaies and Sainte-Rose was conducted. The small village of Deshaies is situated at the end of a relatively narrow bay with the beach length less than $1 \mathrm{~km}$. The bay is bounded by the highest hill on the bay entrance. The underwater shelf is not wide. The depth contour of $20 \mathrm{~m}$ is on the offshore distance of $0.7 \mathrm{~km}$, and the depth contour of $200 \mathrm{~m}$ is on the distance of $4 \mathrm{~km}$. Also, the bathymetry does not show any features indicating the possibility of the wave focus in the bay end, where the main part of the village with two to three streets is located, $1 \mathrm{~m}$ above sea level (Fig. 7 Plate 1a). The church is located behind the streets on the hill, $10 \mathrm{~m}$ above the sea level. We were not able to recognize the church location in 1867 , but the relief features indicate that this should be the same place as the actual one. Since inhabitants took refuge in the church, the possible wave runup could reach $10 \mathrm{~m}$. Certainly such a wave could destroy all the houses on the coast (they are 1-2 floors in the modern village, and have no special defense). Therefore, 

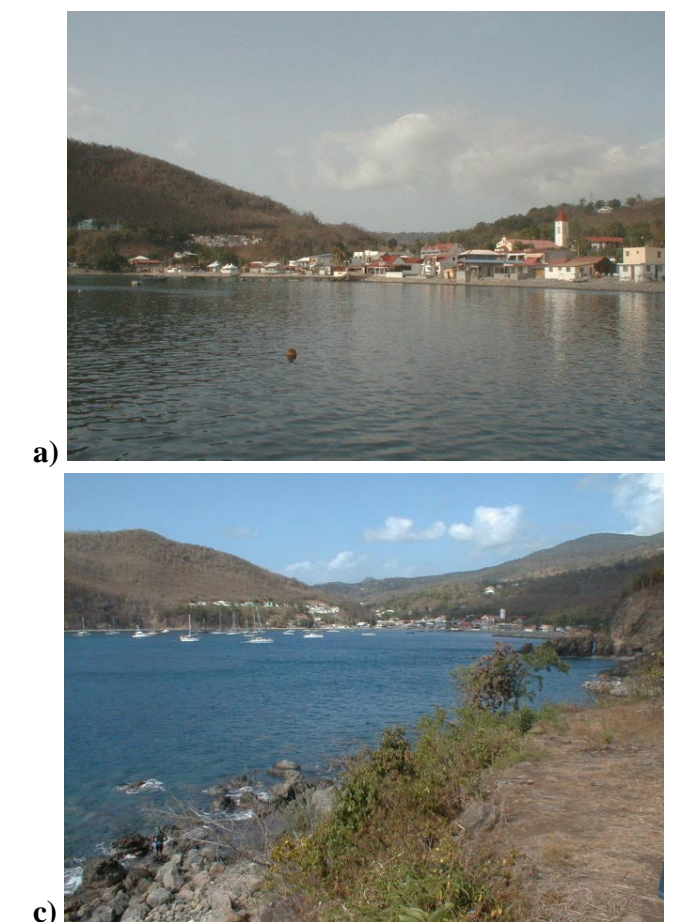

c)

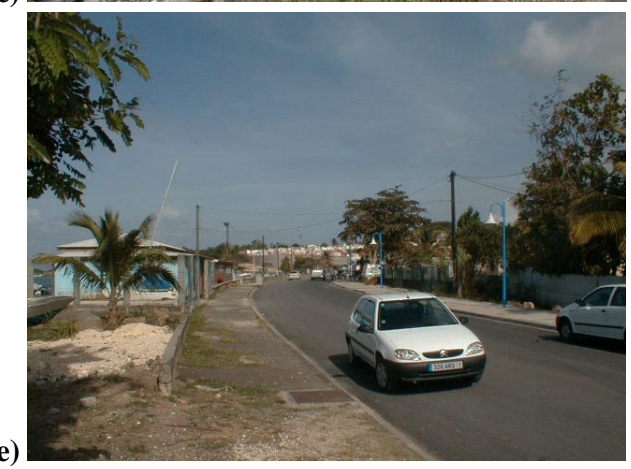

b)

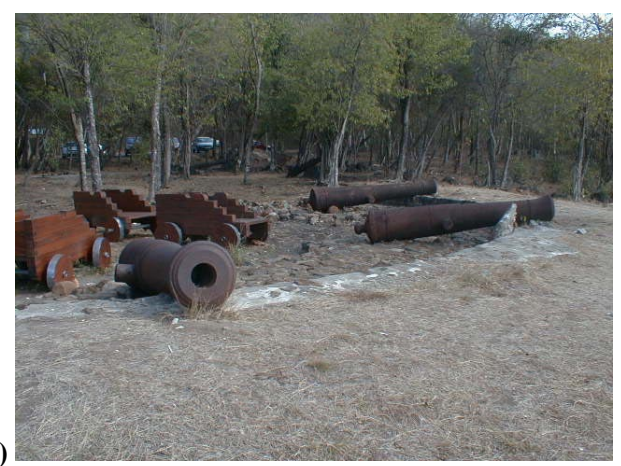

d)

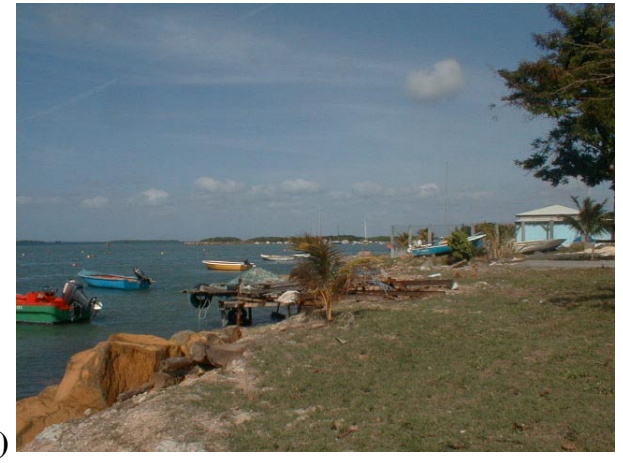

Fig. 7. (a)The view of Deshaies Village (northwestern Guadeloupe Basse-Terre)(the tower on the back is the church).(b), (c) The view of the battery and beach near Deshaies. (d), (e) Beach and St. Rose Village (northeastern Guadeloupe Basse-Terre).

the wave height of $10 \mathrm{~m}$ at Deshaies seems to be real for the 1867 event. As indirect proof, there is an absence of tsunami registration at the battery located on the cliff of $10 \mathrm{~m}$ at the entrance of the bay (Fig. 7, Plates 1b and c). Why inhabitants had time to be saved needs to be analysed. Probably, the wave was high in the open sea, as it was at Sainte-Rose, and people began to run when they saw it. Also, the first wave was negative, as in the other locations and people who experienced the tsunami in $1842 \mathrm{knew}$ that a big wave should come after a "negative" wave.

Concerning the 1842 event at Deshaies, it is difficult to have definite conclusions. First, a $18 \mathrm{~m}$ wave should have destroyed the village, but this is not mentioned in the descriptions. Second, there are no descriptions of the 1842 event in the letter (Sainte-Claire Deville, 1867), written 25 years after 1842; but this letter contains a lot of description about the 1843 earthquake, having taken place practically at the same time as the 1842 tsunami. Therefore, the tsunami at Deshaies in 1842 was weak, and its height probably did not exceed $1 \mathrm{~m}$ (a $2 \mathrm{~m}$ flow flooded the streets at Deshaies, as it did during the cyclone in 1999). But on the other hand, if, in 1867, the people ran away from the tsunami after the first negative wave (if it was in reality), this indicates that people were experienced with tsunami, but the previous tsunami was in 1842 , and therefore, it should have been large.

Sainte-Rose (Fig. 7, Plates $1 \mathrm{~d}$ and e) is a relative large city. It is located on a different altitude, $10-20 \mathrm{~m}$ above sea level. In fact, people were able to be saved on hills from a $10 \mathrm{~m}$ wave. Unfortunately, we have no marks in the descriptions, which we can find on the land. The possibility of determining the $18 \mathrm{~m}$ wave height from the coast, 3 miles in the open sea, seems to be unrealistic, but it cannot be checked. SainteRose is situated on the beach of the very shallow Grand Culde-Sac Marin Bay with the depth less than $20 \mathrm{~m}$ (this depth contour is $7 \mathrm{~km}$ from shore and the depth contour $100 \mathrm{~m}-$ on a distance of $8 \mathrm{~km}$ ). In fact, tsunami waves can be amplified in this shallow bay, and, taking into account the rapid variation of land relief, can focus on some points with large 
values of the runup heights. It means that the wave height can be very high at selected points. But it is more realistic to suppose that the wave height during the 1867 event also did not exceed $10 \mathrm{~m}$ at Sainte-Rose.

Concerning the 1842 tsunami at Sainte-Rose, there is no information on this tsunami in the letter (Sainte-Claire Deville, 1867). It argues in favour of a weak tsunami, and, perhaps, the estimation of the runup of $1.8 \mathrm{~m}$, given by Lander and Whiteside (1997), is more correct.

\section{Conclusion}

The historical data of tsunamis in the Lesser Antilles is collected, analyzed and reviewed. We must underline that this study constitutes a preliminary analysis of tsunami risks in the Lesser Antilles. In total, twenty-four (24) tsunamis were recorded in this area for the last 400 years; sixteen (16) events of seismic origin, five (5) events of volcanic origin and 3 events of unknown source. Most of the tsunamigeneric earthquakes (16) occurred in the Caribbean, and two tsunamis were generated during far away earthquakes (near the Portuguese coast). Detailed analysis of seismicity and landslide parameters, as well as archives of local newspapers dealing with these events, will be in future.

Rough estimations of the cumulative frequency for tsunami appearance have been done for Antigua and Barbados. In the limit of weak tsunami heights, values of the cumulative frequencies coincide, and this indicates the same character of tsunami origin for the Lesser Antilles. Anomalous high values of tsunami height of $18 \mathrm{~m}$ on the Guadeloupe coast are inspected. Tsunami wave heights during the 1867 event probably did not exceed $10 \mathrm{~m}$.

The next step is to perform a numerical simulation of these events in the framework of nonlinear shallow-water theory, including simulation of potential tsunami from hypothetical sources. Results of the numerical simulations of tsunami propagation will be described later.

Acknowledgements. The authors thanks M. Francius and E. Suleimani for assistance to find the references of 1867 and 1920. Particularly, this study was supported by INTAS and EGIDE grant (PAI-RUSSIE) 04500YH. EP had support also from Université des Antilles et de la Guyane.

\section{References}

Affleck: On the agitation of the sea at Antigua: 1 November 1755, Royal Society of London, Philosophical Transactions, Abridged, 11, 9-10, 1809.
BRGM, Service Public du BRGM, Etude et prévention du risque sismique aux Petites Antilles, évaluation de l'aléa sismique sur l'archipel de la Guadeloupe, Rapport de synthèse, 1990.

Bryant, E.: Tsunami: The underrated hazard, Cambridge University Press, 2001.

Calder, E., Young, S., Steve, R., Sparks, J., and MVO staff: The Boxing day collapse, Montserrat Volcano Observatory, Special Report 06, 1998.

Curtis, G. D. and Pelinovsky, E. N.: Evaluation of tsunami risk for mitigation and warning, Sci. Tsunami Hazards, 17, 3, 187-192, 1999.

Choi, B. H., Pelinovsky, E. N., and Hong, S. J.: Simulation of prognostic tsunami on the Korean Coast, Geophys. Res. Letts., 28 , 10, 2013-2016, 2001.

Dorel, J.: Seismicity and seismic gap in the Lesser Antilles arc and earthquake hazard in Guadeloupe, Geophys. J. Roy. Astr. Soc., 67, 679-695, 1981.

Feuillard, M.: Macrosismicité de la Guadeloupe et de la Martinique, Report, Institut de Physique du Globe de Paris, Obsevatoire volcanologique de la soufrière de Guadeloupe, 1985.

Heinrich, P., Mangeney, A., Guibourg, S., and Roche, R.: Simulation of water waves generated by a potential debris avalanche in Montserrat, Lesser Antilles, Geoph. Res. Letts., 25, 9, $3697-$ 3700, 1998.

Heinrich, P., Roche, R., Mangeney, A., and Boudon, G.: Modéliser un raz de marée crée par un volcan, La Recherche, 318, 67-71, 1999a.

Heinrich, P., Guibourg, S., Mangeney, A., and Roche, R.: Numerical modeling of a Landslide-Generated Tsunami Following a Potebtial Explosion of the Montserrat Volcano, Phys. Chem. Earth (A), 24, 2, 163-168, 1999b.

Lander, J. F. and Whiteside, L. S.: Caribbean tsunamis: an initial history, http://rmoclis.upr.clu.edu/tsunamis/ Lander/J\_Lander.html, 1997.

Murty, T.: Seismic Sea Waves - Tsunamis, Canada, Bull. 198 Dep. Fisheries, Ottawa, 1977.

Pelinovsky, E. N., Kharif, C., Riabov, M., and Francius, M.: Modelling of tsunami propagation in the vicinity of the French coast of the Mediterranean, Natural Hazards, 25, 2, 135-159, 2002.

Reid, H. F. and Taber, S.: The Virgin Islands Earthquakes of 18671868, Bull. Seismol. Soc. Amer., 10, 9-30, 1920.

Sainte-Claire Deville, M. Ch.: Sur le tremblement de terre du 18 novembre 1867 aux Antlles, Comptes Rendus, Acad. Sci., Paris, 65, 1110-1114, 1867.

Smith, W. H. F. and Sandwell, D. T.: Global Seafloor Topography from Satellite Altimetry and Ship Depth Sounding, Science, 277 1956-1962, 1997.

Soloviev, S. L., Solovieva, O. N., Go, Ch. N., Kim, Kh. S., and Shchetnikov, N. A.: Tsunamis in the Mediterranean sea 2000 B.C. - 2000 A.D., Advances in Natural and Technological Hazards Research (Kluwer), 13, 2000.

Weissert, T. P.: Tsunami travel time charts for the Caribbean, J. Tsunami Society, 8, 2, 67-77, 1990. 